\title{
凡毕 VIEWS.
}

I.-Textbook of Geologr. By Arohibald Geikie, F.R.S., LL.D., Director-General of the Geological Survey of Great Britain and Ireland. (London: Macmillan \& Co., 1882.)

(Continued from p. 42.)

J $\mathrm{N}$ the body of his work Dr. Geikie arranges his subject-matter under the following heads: 1. The Cosmical Aspects of Geology.

2. Geognosy. 3. Dynamical Geology. 4. Structural Geology. 5. Palæontological Geology. 6. Stratigraphical Geology. 7. Physiographical Geology. Thus, in his mode of presentation of the subject, the author has, either with unconscious natural proclivity, or with well-considered art, selected that especial method of treatment which of all others commends his work to the prejudices of educated men in general, and he repeats in his plan the natural method of history itself. Feeling, doubtless, how incapable are the unimaginative and inelastic ideas of the old empirical school of British geology, of popular and artistic treatment, he deliberately cuts himself adrift from its society at the outset, and sails triumphantly away into the ranks of the new cosmologists. Ife points out how, in the infancy of the science, men commenced the study of geology by the adoption of some fanciful hypothesis of the origin of our planet, or of the universe, of which it is a part. He gracefully acknowledges that, thanks to the teaching of the illustrious Hutton and to the labours of the Geological Society of London, geologists learnt that it is no part of the province of their science to discuss the origin of things. But in this the Doctor sees nothing more than a very natural reaction. He owns that geology is never likely to discover even so much as a fragment of the first crust of the earth. But if geology has not yet attempted a cosmology, other sciences have done so. The average mind, he seems to imply, naturally desires a cosmology, and we must provide one.

Founding upon the nebular hypothesis of Kant and Laplace, the anthor therefore gradually developes, before the eyes of the reader, a consistent scheme of earth-evolution, buttressing every stage either with acknowledged facts, or with authoritative theories gathered from the most recent literature in speculative physics, chemistry, and astro. nomy. The manifold mathematical and physical conclusions of Sir W. Thoinson, the latest guesses of Mr. Lockyer, the tidal hypotheses of Mr. G. F. Iarwin, and the attractive speculations of Dr. Croll, are all laid under contribution. Interspersed with numerous and well-selected astronomical or physical facts, these are employed by the author as factors of almost equal value with the latter in the construction of an introductory cosmical section of wonderful symmetry and plausibility. It is impossible for the reader to refuse his admiration of the skill which could thus group such heterogeneous elements into so complete and consistent a whole. It is graceful and harmonious as a rainbow, and destined, alas! by the very nature of things to be almost equally evanescent. But, aerial as it is, it serves several purposes. It permits of the grouping of the more imposing points 
in the forefront of the book. It appeals to the intellect and imagination of the educated reader, and that upon his most vulnerable side, and compels his keen interest in the subject at the very commencement.

In the second division of the volume (Book II.) the author treats of the fully developed earth of the present; here, as everywhere throughout the work, following invariably the same order in his descriptions;-proceeding from the general to the special, from without, inwards. In the first section of this Buok, he carries the reader in imagination through the outer coverings of air, water, and visible earth-crust, until he stands with him once more peering curiously into the mists of recent speculation respecting the actual state of the earth's interior. Nearly one-half of this sub-section is devoted to the discussion of the various theories hitherto advanced as to subterranean heat and pressure, and the probable extent of geological time. The diverse results of Hopkins, Delaunay, Thomson, Mallet, Darwin, and Fisher, are all passed in review. One can hardly avoid the inference that the author has a leaning towards the views of the Scottish authorities, and one would personally have preferred a much fuller treatment of the views of Fisher and Le Conte; but upon the whole this sub-section is the best summary of opinion we actually possess.

The second section of the Book (Book II. Part 2) is devoted to a description of the minerals and rocks which constitute the accessible earth-crust. From beginning to end of this part we feel that we are in the presence of a master of his subject, one who is familiar with every stage, and knows how to smooth over every difficulty. After a brief glance at the main chemical rock-forming elements, the author passes on rapidly to the chief rock-forming minerals, giving just such descriptions as are generally capable of verification by hand-specimens, and carefully avoiding all mineralogical terms but such as are actnally necessary. While we heartily sympathize with him in his avoidance of long definitions of crystalline forms, we can hardly help regretting that at least a short sketch of the chief crystalline types and their major derivatives had been inserted for the benefit of those private students of the science who have no leisure to follow out a complete mineralogical course, and to whom, as a consequence, many of the definitions on pages 63 to 85 will be partly incomprehensible.

To the sub-section which follows (Sect. IV.) treating chiefly of the microscopic characters of rocks, and which is essentially a new feature in geological text-books, no exception can be taken; it is excellent throughout.

But in the next section (Section V.), which is devoted to lithology, it does not appear to us that the Author is quite so successful. He classifies rocks under the two main beads-crystalline and clastic, dividing the former into stratified, foliated, and massive; and the latter into sands, clays, tuffs, and fragmental organic rocks. As a consequence of this arrangement, compact limestone finds a place at one end of the entire rock-series, and chalk almost at the other;

\footnotetext{
DECADE II. - VOL. X.-No. II.
} 
quartzite, under one form or another, makes several distinct appearances; clay-slate and shale are divided from each other by the entire group of volcanic rocks; and so on. Surely the old-fashioned arrangement of rocks into aqueous, igneous, and metamorphic was much more manageable than this; and it is hardly likely that such a thorough-going believer in the power of metamorphism as Dr. Geikie would have found any insurmountable difficulty in classifying the individuals in his major groups according to their degree of alteration, and making them teach the special lesson which it is clear he desires them to convey.

The third division (Book III.) of the volume is devoted to an account of the agencies at present engaged in geological evolution. These agencies are classed as hypogene and epigene, and the subject is treated with an exhaustiveness that leaves nothing to be desired. Geologists have long been aware of the interest Dr. Geikie has taken in this special branch of his science, but we were hardly prepared for such a masterly command of the entire subject as he has developed in these pages. In selection and arrangement of material, in sequence and proportion, this section appears to us to leave everything hitherto attempted in geological text-books in this special department far behind. Every conspicuous fact and conclusionn having a geological bearing hitherto published has its proper place in the compilation. It covers the ground embraced generally within the limits of Lyell's "Principles," and bespeaks an enthusiastic student of that immortal work. But the student has now become a master in his turn and has his own story to tell: and admirably be tells it. Every word falls with its proper weight and has its due effect.

Having fully discussed the great earth-crust-builders and sculptors, Dr. Geikie next takes the reader to the study of the architecture of the great building itself, and treats in succession of the phenomena of stratification, fracture, protrusion, and metamorphism. As a whole this section is most extended and complete; but it is very unequal in parts, and when contrasted with the foregoing sections appears to us to be most decidedly inferior. For the unavoidable drudgery of mapping and sectioning the author appears to have lost much of his former zest. Some instructive examples of inversion are inserted from Heim's magnificent memoir, but we trust that in a future edition we shall see corresponding examples from British localities. They are plentiful enough in some areas in our islands, and display almost every phenomenon illustrated by Heim.

In his description of intrusive and volcanic rocks, however, Dr. Geikie is himself again, and both in description and illustration the paragraphs are admirable.

But it is in the sub-section upon metamorphism that the author's interest becomes fully aroused. He very carefully distinguishes between local and regional metamorphism, tracing the effects of the former, by means of well-authenticated examples stage by stage until he demonstrates the possible transformation of ordinary clastic in to actual crystalline rocks. But where he treats of regional meta- 
morphism his arguments are much weaker, and some of them will have no weight whatever with many British geologists. In effect, so far as Britain is concerned, his argument rests largely upon the asserted fact that the Highland metamorphic rocks of the north-west of Sutherland and Ross "demonstrably overlie fossiliferous Lower Silurian rocks." Now we are not among those who deny the possibility of the transformation of aqueous into crystalline rocks by means of regional metamorphism, or the probability that altered equivalents of some of the $\mathrm{S}$. Scottish Silurian rocks do actually occur in the Highland region. But we so distinctly believe the fact that the truly metamorphic rocks of the north-west do not overlie and follow the fossil-bearing rocks in natural sequence can be so fully proved in the field, that we feel this threadbare argument ought soon to wholly disappear from the controversy. We hope that the timid little section on page 584 of Dr. Geikie's work, by which this specious, but moribund, view is illustrated, is destined to be the last of its race to be pressed into this unnatural service.

The fifth eection of the work (Book V.), on Palæontological Geology, may be looked upon as an introduction to the purely stratigraphical and theoretical division of the subject. It contains some well-considered paragraphs, but the author chafes visibly under the curb imposed by the doctrine of geological contemporaneity; and the instinct of self-preservation leads him to make much of the handy theory of colonies-that convenient refuge for the stratigraphic destitute. He parallels the famous colonies of Bohemia with the well-known fossil-bearing bands in the Silurian of South Scotland. We believe this comparison to be the best that could be made. In both areas the disputed successions are founded upon corresponding appearances, and in both cases the belief in the orthodox view is probably destined soon to be confined solely to its authors. Both are, however, valuable warnings, with which the future student of historical geology could ill afford to dispense. One is the fruit of palæontology without stratigraphy - the other of stratigraphy without palæontology.

In Book VI. we enter upon the subject of Historical Geology itself. Although the author is careful to impress the student with the fact that this is unquestionably the highest branch of the science, yet it is evident enough that, in his own eyes, as in those of the vast majority of modern physical geologists in sympathy with him, it has rather the appearance of an oppressive nightmare of piles of undigestible facts and meaningless strings of names. Since the death of Edward Forbes, the breath of British genius has never swept over this valley of dry bones, and the man has yet to arise who shall summon them again into life, and demand from them the final solution of the great riddle of evolution, which the patient embryologists and dreamy cosmogonists of the present are vainly seeking for elsewhere. These facts in themselves have clearly little attraction for the author, except in so far as they are connected with his own life-work and with former supposed phases of earth development. For the purely palæontological department of the subject, he does not attempt to 
disguise his own want of sympathy. On the stratigraphical side he generally coincides with the majority of the day.

Nevertheless he has compiled a section of some 300 pages on palæontological and historical greology, which for extent and completeness is unequalled by anything yet published in Britain. Among the older rocks be is heavily handicapped by his intense anxiety to defend the peculiar position he has adopted with respect to the age of the Metamorphic rocks of the Highlands, and the sequence in the Southern Uplands, and by his amusing reluctance to admit that any British-born subject who has not been, or is not, a nember of H. M. Geological Survey, can possibly produce anything worthy of notice in Geology. But when he once gets fairly out of the Silurian maze, his work is excellent. Every system in the ascending scale is described as a whole, the essential features of its rocks, and its special life types. Next, the local variations in its rock formations are noticed in order, commencing with Britain, and passing thence to Europe, America, Asia and Australia. Every page bears the impress of intense labour and care. No pains appear to have been spared to make the section a complete sunimary of onr present knowledge of the subject, and the student of comparative geology will find it an excellent work of reference, easy of search, and as a general rule thoroughly reliable.

Finally, we have a comparatively brief section (Book VII.) restricted to the discussion of the evolution of the present land and water contour, or - as the author prefers to call it - to Physiographical Geology. This is merely a short summary of the broader facts and of the accepted theories of elevation and denudation, and is very modest and temperate in tone throughout.

Looking back over the work as a whole, we see no reason for modifying the opinion expressed in the earlier paragraphs of this notice. Dr. Geikie's "Handbook" is the most readable and complete work upon the entire subject yet issued to the public, and will prove of great value not only to the earnest student, but to all who are interested in the science of geology. To the practised geologist it has an especial value, from the fact that it is a very accurate presentation of what may be called the prevalent shade of geological opinion in Britain. It is an exponent of the ideas of that increasing number of geologists, who, whatever may be their professed tenets, unquestionably act and live as if the study of the materials and outward aspect of the great earth-building were the be-all and the endall in geology. The moral the non-geological reader is certain to draw from a first perusal of the work is that while the study of rockspecimens and of the effects of geological agencies demands and is worthy of the life-long devotion of the geologist, and that at the last he is but a simple student, whose accumulated knowledge is but the merest fraction of the great sum of truth; yet, in the domain of historical and palæontological geolngy, any one who can take a dip or a strike, or can make a rough identification of a fossil from some standard monograph, is as good as the best. In the physical half of the work the author is himself a student among students, all aglow 
with interest and enthusiasm, so full of his subject, and so anxious for light and knowledge, as to be able to recognize at a glance the import and value of the work of others, and willing to allow that the humblest observer may arrive at a part of the truth. In the stratigraphical half his interest is less living and personal, and his work nccasionally becomes perfunctory, didactic and defensive. His official position as Director-General of the Geological Survey, and the traditions of his school, forbid his calm presentation of the views of all sections, and force him into the position of an exponent and apologist of the views of his office and party; and he becomes the grave teacher and the infalible authority, cold and unsympathetic, whose ipse dixit is final and conclusive. We feel assured that in both departments his work will bear its natural fruits. For one who will painfully wade through his elaborate section on Stratigraphical geology, hundreds will study the physical chapters with pleasure and with profit.

The veterans of the old British school of Hutton, Lyell, and William Smith, will bail the appearance of this volume with unalloyed pleasure. The finest and most attractive portion of the work - that upon Dynamical Geology - is filled with the very spirit of Lyell himself. In the elaborate paragraphs of his stratigraphical sections, and in his strenuous advocacy of the Colonial theory, the author is preparing a magnificent tribute to the memory of William Smith. In the vagine and nebulous beauty of his own provisional cosmogony he affords us a new and striking demonstration of the fact that there is no rest for the sole of the foot but upon the great principle of Hutton. The spirit of restless inquiry, of search after absolute truth, raised in the first half of the work will not be stilled by anything in its later pages. These earlier portions are certain to attract students, and will form the very best possible training for the thorough investigation of those higher branches of the science, which, of late years, have been so sadly neglected in Britain. The straining after picturesque provisional generalizations, the confusion of fact and opinion, and the affectation of non-recognition of all but properly constituted authority, rarely, but occasionally met with in its pages, and which jar upon the feelings of the modest and conscientious worker in the science, constitute a fresh proof, if any were required, of the necessity for the members of the Geological Society of the present to hold fast and firm to their fundamental rule of "collecting facts, instead of fighting over hypotheses."

In the light of these facts, as they gradually develope themselves in the immediate future, the rising race of young geologists will see for themselves that our science is still in its very infancy-and that some of the mightiest problems in British geology yet await solution. Out in the wholesome air of individual liberty of opinion, free from the stifling restrictions of party or office, it will be theirs to solve them as did their fathers in the past. In the earlier pages of Dr. Geikie's charmingly written volume they will find the means of doing this 
work. In its later pages they see before them the present horizon of authoritative opinion in Britain in advancing from which they have an unfailing means of estimating their onward progress.

Chas. Lapworth.

II.-Obersilurische Koraleen von Tshad-Tï̈n im Nordöstlichen Theil der Provinz Sz-Tshwan. Von Herrn G. Lindström, in Stockholm. [Upper Silurian Corala rrom Thaad-Tien in the North-Eastern Part of the Province Sz-Tshwan. By Dr. G. Lindström. 4to. pp. 24, with Three Plates.]

T $N$ this treatise, which will be included in the forthcoming volume 1 of the Baron von Richthofen's great work on China, Prof. Lindström describes a series of corals entrusted to him for this purpose, by that distinguished traveller, who collected them in the course of one of his journeys in Northern China. The corals are of Silurian age; the beds containing them are regarded by Lindström as homotaxial with the English Wenlock and the Wisby series of Gotland. There are in all eighteen species belonging to eleven genera. Ten of the species are new forms, and three new genera are defined. It is interesting to observe in this outlying Silurian area, the occurrence of such familiar genera as Favosites, Heliolites, Plasmopora, Halysites, Amplexus, Cyathophyllum, Ptychophyllum, and Cystiphyllum. Of the new genera, the most interesting is a compound coral, named Somphopora, with completely perforate walls and six short spinous septa in each oorallite. It appears to be closely allied to the existing genus Alvenpora, and furnishes another example of the occurrence of corals of the order Perforata in the Palæozoic rocks.

Another genus, named Ceriaster, in exterior appearance resembles Columnaria, but it possesses interior dissepiments and increases by intracalicular budding. We may remark that the figures of this coral very strongly remind us of the Coltmnaria alveolata, Goldfues, and in another species, C. calirina, Nicholson, the increase is partly by calicular gemmation, of an apparently similar character to that which takes place in Ceriaster.

The remaining new genus, Platyphyllum, is, in the form of the cup, like Calceola or Rhizophyllum, and in the interior structure, closely similar to Goniophyllum. The summit appears to have possessed a single operculum-plate like Calceola, but up to the present the operculum of this coral has not been discovered.

In addition to the description of the new forms, Professor Lindström discusses some disputed points touching the structure, affinities, and synonyms of some of the long-known Silurian corals. We can here only refer to one or two of these points, and the first relates to the characters of the small tubular structures which intervene between the cylindrical corallites in the genus Heliolites. Up to a recent period these tabulated tubes were regarded as conenchymal in character, but lately Prof. Nicholson" described them as "probably

1 Palæont. 2nd ed. vol. i. p. 221. 